\title{
Dziecięce wyobrażenia paidii
}

\begin{abstract}
This chapter consists of two parts: theoretical background and case studies. It aims at presenting children's fantasies or mental images (be it verbal or iconic) of paidia as a word. The first part is dedicated to the investigations into children's imagination, stages of its development, and factors that affect it. The other part analyses the works of 51 pupils who were supposed to draw "a paidia" and reads the ways they both concretised it on the pictures and described them.
\end{abstract}

Keywords: imagination, fantasy, children's imagination, paidia, stages of child imaginative development

\section{Wprowadzanie}

W swoim studium Ewa Podrez i Antoni Czyż napisali, że „Wyobraźnia, gdy staje się narzędziem filozoficznych odczytań świata, musi znać granicę swych możliwości" (Czyż, Podrez, 2002, s. 25). Tymczasem wyobraźnia dziecka jest nieograniczona: nieograniczona nie tylko teoriami filozoficznymi, lecz nieograniczona niczym ${ }^{1}$. Wyobraźnia i paidia łączą się ze sobą. Zabawa to nie tylko metoda rozwijania wyobraźni, ale też miejsce, w którym wyobraźnia „spełnia się”, a wyobrażenia stają się rzeczywistością.

Artykuł stanowi próbę ukazania dziecięcych wyobrażeń (fantazji) słowa paidia. Wyniki badań zostaną poprzedzone refleksją na temat wyobraźni dziecka, etapów jej rozwoju oraz czynników ją kształtujących.

\section{Wyobraźnia}

Termin „wyobraźnia” ma swój odpowiednik w wielu językach: angielskim (imagination, fantasy, fancy), niemieckim (Phantasie, Einbildung, Vorstellungs-

${ }^{1}$ Mam na myśli początkowy etap jej rozwoju, etapy kolejne (por. tabelę 1.) uwidaczniają, że otoczenie, środowisko, normy, konwenanse, proces edukacji w szkole ograniczają spontaniczną produktywność, wyobraźnię i fantazję dziecięcą. 
kraft), francuskim (l'imagination, le rêve, la fantaisie), włoskim (immaginazione), hiszpańskim (imaginación), rosyjskim (воображение)².

Słowniki języka polskiego ${ }^{3}$ zawierają definicje zarówno wyobraźni, jak i wyobrażenia (ujmowanego w osobny artykuł hasłowy lub stanowiący rozszerzenie pojęcia „wyobraźnia”). Inny słownik języka polskiego PWN następująco definiuje te terminy: „wyobraźnia” to:

1. Zdolność wyobrażania sobie sytuacji, osób, zjawisk itp., których dotąd nie widzieliśmy ani nie doświadczyliśmy w inny sposób [...]. 2. Ta część naszego umysłu, dzięki której wyobrażamy sobie coś, czego nie widzieliśmy ani nie doświadczyliśmy w inny sposób...

Bańko, red., 2000, s. 1123

„Wyobrażenie” definiowane jest następująco:

1. To rzeczownik od 'wyobrazić. 2. Nasze wyobrażenie o czymś to nasza wiedza lub opinia o tym, często powierzchowna, niepełna lub wręcz fałszywa [...]. 3. Wyobrażenie jakiejś osoby lub rzeczy [...].

Bańko, red., 2000, s. 1124

Wyobraźnia ściśle powiązana jest z twórczością, można wyróżnić wyobraźnię twórczą (wytwarzającą wyobrażenia twórcze, fantazję) oraz odtwórczą (wytwarzającą wyobrażenia odtwórcze). Wyobrażenia „zawierają element różnych zapamiętanych przez człowieka fragmentów rzeczywistości i nie są mechaniczne" (Górniewicz, 1992, s. 6). Psycholodzy wyodrębniają cechy, które odróżniają wyobrażenia od spostrzeżeń (lub halucynacji). Najważniejszą jest wysoki stopień podobieństwa pomiędzy realnym obiektem a wyobrażeniem. Tworzenie wyobrażenia nie wymaga widzenia kreowanego obiektu. Wyobrażenie jest wreszcie mniej wyraziste i niestabilne w porównaniu ze spostrzeżeniem, najczęściej pierwszoplanowy obiekt wyobrażenia (np. melodia, zapach, postać) okazuje się silniejszy niż towarzyszące mu tło (Zdankiewicz-Ścigała, Maruszewski, 2008, s. 184).

Dla opisywanej w artykule problematyki znaczenie ma zdefiniowanie pojęcia „fantazja”, które Słownik wyrazów obcych definiuje jako:

(gr. phantasia) 1. wyobraźnia twórcza, zdolność do fantazjowania, do wyobrażania sobie czegoś. 2. zmyślenie, urojenie, wymysł. 3. zachcianka, kaprys, dziwactwo. [...] 6. zuchowatość, odwaga, pewność siebie, animusz.

Tokarski, red., 1980 , s. 210

2 Tłumaczenie pochodzi z http: www.ling.pl/index.jsp [data dostępu: 15.06.2018].

3 Analizowałam hasło „wyobraźnia” w następujących słownikach języka polskiego: Dubisz, red., 2003; Bańko, red., 2000; Bańko, red., 2003.

${ }^{4}$ Więcej na ten temat: Limont, 1996. 
Wyobraźnię umiejscawia się w różnych obszarach ludzkiej psychiki: kreująca nowe obrazy (znajduje się w pobliżu myślenia oraz inteligencji) wyobraźnia odtwórcza bliższa jest pamięci. Tworzenie się nowego obrazu umysłowego przebiega na kilku etapach:

- dysocjacja - rozkładanie elementów zawartych w pamięci na elementy mniejsze (podział elementów na mniejsze powoduje, że przydzielane są im nowe znaczenia),

— asocjacja - kojarzenie materiału ze sobą za pomocą reguł,

- synteza - powstaje wytwór wyobraźni; najczęściej początkowo nieuświadomiony, dopiero później wyobrażenia jako wytwór wyobraźni zostają uchwycone (Tokarski, red., 1980, s. 7-9).

Początek XX wieku (1906 rok) przynosi pierwszą w psychologii i naukach pokrewnych całościową koncepcję wyobraźni twórczej ${ }^{5}$ stworzoną przez Théodule'a A. Ribota (za: Jankowska, 2015, s. 288); wcześniej w tym zakresie badania prowadził Francis Galton. W latach trzydziestych XX wieku autorską koncepcję wyobraźni twórczej proponuje Lew S. Wygotski (Wygotski, 2004, s. 7-97). Badacz wiąże ściśle wyobraźnię (nazywa ją kombinatoryczną) z doświadczeniami jednostki, uznaje, że rozwój imaginacji następuje pod wpływem języka. Nieco później (lata siedemdziesiąte i osiemdziesiąte XX wieku) teorię fantazji (twórczej wyobraźni) wprowadza Igor M. Rozet (Rozet, 1982). Lata dziewięćdziesiąte XX wieku oraz badania Thomasa B. Warda owocują koncepcją wyobraźni ustrukturalizowanej (Ward, 1994, s. 1-40),

której działanie sprowadza się do generowania nowych fragmentów wiedzy w ramach istniejących dziedzin. Za proces ten odpowiada zdolność poszerzania pojęć [...], czyli nadawania nowej struktury pojęciom, np. poprzez dodawanie nowych cech.

Jankowska, 2015, s. 298

Współczesne koncepcje wyobraźni opierają się na zdobyczach neurologii i neuronauk. Stephen Kosslyn twierdzi, że „kora wzrokowa pełni podstawową funkcję zarówno podczas procesów percepcyjnych, jak i wyobrażeniowych” (Francuz, 2007, s. 15).

Duży wkład w kształt pojęć „wyobraźnia” i „wyobrażenia” w duchu fenomenologicznym włożył Jean Paul Sartre (1940), poświęcając uwagę nie tylko rozu-

${ }^{5} \mathrm{~W}$ prezentacji teorii związanych z wyobraźnią ograniczę się do kilku najważniejszych. Szczegółowej analizy tego zagadnienia w odniesieniu do rozumienia wyobraźni w różnych dziedzinach wiedzy podjęła się Wiesława Limont w swoim studium Analiza wybranych mechanizmów wyobraźni twórczej. Badania eksperymentalne (por. rozdział 1. pt. Wyobraźnia, w którym zaprezentowano pojęcie oraz koncepcje wyobraźni). Dokonano analizy porównawczej myślenia wyobrażeniowego oraz twórczości, by zaprezentować rozwój myślenia wyobrażeniowego, wyobraźni oraz twórczości dzieci. Por. Limont, 1996, s. 9-54. 
mieniu wyobrażenia, lecz także roli wyobrażeń w życiu psychicznym i wyobrażeniowym.

Jak napisał przed laty John Masefield, „człowiek składa się z ciała, umysłu i wyobraźni; jego ciało jest niedoskonałe, jego umysł zawodny, ale jego wyobraźnia uczyniła go znakomitym” (Masefieled za: Selye, 1967, s. 50). Mimo tego odważnego stanowiska początkowo wyobraźnia i jej rola były niedoceniane. Co więcej, obecnie działania twórcze są równie często ograniczane na rzecz działań odtwórczych, wymaganych w danej sytuacji od dziecka w poleceniach nauczyciela czy autora podręcznika. W badaniach naukowych wielokrotnie zwraca się uwagę na zależności pomiędzy wyobraźnią (zarówno wizualną, jak i twórczą) oraz kreatywnością (głównie myśleniem dywergencyjnym) (Dobrołowicz, 1991, s. 7-23). Wyobraźnia ułatwia także zapamiętywanie (choć zwraca się również uwagę na zjawisko inflacji wyobraźni i możliwe zniekształcenia pamięciowe) oraz pozwala kształcić niektóre sprawności motoryczne ${ }^{6}$.

Tabela 1

Stadia rozwoju wyobraźni dziecka

\begin{tabular}{|l|l|}
\hline \multicolumn{1}{|c|}{ Stadium rozwoju wyobraźni } & \multicolumn{1}{c|}{ Charakterystyka } \\
\hline $\begin{array}{l}\text { Wyobraźnia odtwórcza, naśladowcza } \\
\text { (ok. 1._3. roku życia dziecka) }\end{array}$ & $\begin{array}{l}\text { Wyobrażenia mają charakter głównie odtwórczy: pod } \\
\text { koniec tego etapu dziecko potrafi wyobrazić sobie róż- } \\
\text { ne elementy w zabawie, dominuje animizm (ożywianie } \\
\text { rzeczy martwych i nadawanie im ludzkich cech). } \\
\text { W zabawach przeważa realizm (prezentowanie tego, co } \\
\text { się doświadczyło). }\end{array}$ \\
\hline $\begin{array}{l}\text { Wyobraźnia twórcza i spontaniczna } \\
\text { (ok. 3.-6. roku życia dziecka) }\end{array}$ & $\begin{array}{l}\text { W zabawie dominują fikcja i iluzja. } \\
\text { Dziecko żyje równolegle w świecie realnym oraz wy- } \\
\text { obrażonym. Świat „na niby” jest dla dziecka tak samo } \\
\text { ważny, jak świat realny. } \\
\text { Wyobraźnia jest w pełni mocy twórczych. }\end{array}$ \\
\hline $\begin{array}{l}\text { Wyobraźnia z pogranicza } \\
\text { (racjonalna i twórcza) } \\
\text { (ok. 6.-9. roku życia) }\end{array}$ & $\begin{array}{l}\text { Z jednej strony dziecko ma mniej możliwości do spon- } \\
\text { taniczności i kreatywności na zajęciach szkolnych (wy- } \\
\text { obraźnia jest kierowana przez nauczyciela), z drugiej } \\
\text { zaś, korzystając z zajęć pozalekcyjnych, poznaje nowe } \\
\text { formy twórczego działania. }\end{array}$ \\
\hline $\begin{array}{l}\text { Wyobraźnia racjonalna } \\
\text { (ok. 9.-12. roku życia) }\end{array}$ & $\begin{array}{l}\text { Widoczne są symptomy kryzysu twórczego. } \\
\text { Szkoła stanowi ważne źródło stymulujące wyobraź- } \\
\text { nię: pozwala eksperymentować i eksplorować otacza- } \\
\text { jący świat. Działania ucznia są bardziej racjonalne niż } \\
\text { twórcze. }\end{array}$ \\
\hline
\end{tabular}

Opracowanie własne na podstawie: Górniewicz, 1992, s. 31-38.

${ }^{6}$ Więcej na temat praktycznych zastosowań wyników badań nad wyobraźnią por. Falkowski, Maruszewski, Nęcka, 2011, s. 399. 
Psychologowie spierają się, czy istnieje jedna globalna wyobraźnia, czy funkcjonują tylko poszczególne jej odmiany: wyobraźnia przestrzenna, plastyczna, muzyczna, konstrukcyjna itp. Spór o istnienie nadrzędnej, głównej wyobraźni ${ }^{7}$ przekłada się na możliwość badania tego konstruktu. Nie istnieje jedno narzędzie do pomiaru tej dyspozycji psychicznej, można natomiast określić poziom konkretnej wyobraźni. I tak, przykładowo, wyobraźnię konstrukcyjną bada test Halla, przestrzenną - test Joya P. Guilforda, twórczą - Test Twórczych Zdolności Wyobrażeniowych (TTZW).

Rozwój wyobraźni determinują zarówno geny, jak i wpływ środowiska (im bardziej jest ono zróżnicowane, tym lepiej ta funkcja umysłu jest rozwijana). Wyobraźnia wiąże się też ściśle ze zmysłami i z myśleniem. Trudno wyznaczyć etapy kształtowania się wyobraźni, można jednak wyróżnić kilka „kamieni milowych" w jej rozwoju. W tabeli 1 . zostały przedstawione stadia rozwoju wyobraźni dziecka.

Niezależnie od etapu rozwoju na wyobraźnię ma wpływ wiele czynników, takich jak spostrzegawczość, myślenie, sprawności językowe, sprawności manualne, pamięć, koncentracja uwagi, aktywność poznawcza (duże znaczenie odgrywa temperament), aktywność fizyczna, poziom dojrzałości społecznej dziecka (szczególnie umiejętność komunikacji interpersonalnej), rozwój moralny i społeczny, postawa otoczenia wobec działań twórczych dziecka, środowisko wychowawcze i szkolne.

\section{Jak dzieci wyobrażają sobie słowo paidia? Opis badania}

Celem badania była próba znalezienia odpowiedzi na pytanie, w jaki sposób dzieci wyobrażają sobie słowo paidia. Zadaniem dzieci było zarówno rysunkowe przedstawienie, jak i sformułowanie definicji. W badaniu wzięło udział pięćdziesięcioro jeden dzieci, w tym dwadzieścioro sześcioro uczniów z klas I-III oraz dwadzieścioro pięcioro uczniów z klas IV-VI ${ }^{8}$. Było to zadanie dodatkowe dla chętnych uczniów wykonywane w domu oraz zaprezentowane w szkole podczas zajęć.

Przed opisem wyników badań warto odpowiedzieć na pytanie: czym jest paidia?. Pavol Winczer (powołując się na prace Rogera Caillois, 1973) definiuje ją następująco: „[...] beztroska zabawa, swobodna działalność wyobraźni, impro-

7 W swoim studium Józef Górniewicz przyjmuje hipotezę, że „istnieje jedna niepodzielna wyobraźnia”. Górniewicz, 1992, s. 15.

${ }^{8}$ Wśród badanych znaleźli się uczniowie Szkoły Podstawowej nr 118 we Wrocławiu, Szkoły Mistrzostwa Sportowego w Zabrzu oraz Szkoły Podstawowej nr 33 w Zabrzu. Dzieci młodsze udzielały ustnej odpowiedzi, którą notował nauczyciel podczas prezentacji pracy na lekcji, ponieważ najmłodsi uczestnicy badania nie potrafili jeszcze pisać. 
wizowana, niekontrolowana i niezobowiązująca aktywność, która jest żywiołowym przejawem witalności i potrzeb odprężenia” (Winczer, 1976, s. 8). Paidia wywodzi się z greckiego pais — „dziecko” (Jaeger, 1962, s. 6). Pojęcie paidia kontrastuje z ludus, czyli ze spętaniem konkretnymi regułami, z brakiem swobody. Paidia jest również „wyznacznikiem artystycznie wartościowej twórczości dla dzieci i jej nieodłączną cechą" (Ostasz, 2011, s. 83).

\section{Paidia oczami dziecka}

Zanim zostanie przedstawiona szczegółowa analiza rysunków dzieci, warto zauważyć, że większość ilustracji jest kolorowa, egzotyczna, bardzo częsty motyw stanowi tęcza. Tabela 2. zawiera zestawienie wyników analizy treści rysunków dziecięcych.

Tabela 2

Jak dzieci wyobrażają sobie słowo paidia

\begin{tabular}{|l|c|c|}
\hline \multicolumn{1}{|c|}{ Paidia-skojarzenia } & $\begin{array}{c}\text { Uczniowie klas I-III } \\
\text { N = 26 }\end{array}$ & $\begin{array}{c}\text { Uczniowie klas IV-VI } \\
\text { N }=25\end{array}$ \\
\hline Owoc & 0 & 6 \\
\hline Warzywo & 0 & 5 \\
\hline Potrawa & 1 & 4 \\
\hline Rzecz & 6 & 1 \\
\hline Osoba/postać z bajki & 1 & 1 \\
\hline Stan emocjonalny & 0 & 1 \\
\hline Zjawisko/sytuacja & 1 & 1 \\
\hline Rodzaj muzyki & 0 & 4 \\
\hline Miejsce & 12 & 0 \\
\hline Zwierzę/zwierzęta & 4 & 0 \\
\hline Pora roku & 1 & 25 \\
\hline
\end{tabular}

Dzieci najczęściej wyobrażają sobie paidię jako miejsce (szesnaście osób), coś do jedzenia: owoc, warzywo potrawę (czternaście osób) oraz rzecz (dziesięć osób). Zdecydowanie rzadziej - jako inny element ożywiony: zwierzę (cztery osoby), osobę/postać z bajki czy zjawisko/sytuację (po dwie osoby). Pojedynczy uczniowie wyobrażali sobie paidię jako porę roku, rodzaj muzyki czy stan emocjonalny. Na uwagę zasługują również definicje słowa paidia (opisy rysunków). $\mathrm{W}$ tabeli 3. zostały zaprezentowane wyniki badań. 
Dziecięce opisanie/definiowanie paidii ${ }^{9}$

\begin{tabular}{|c|c|c|}
\hline Paidia - skojarzenia & $\begin{array}{l}\text { Uczniowie klas I-III } \\
\qquad \mathrm{N}=26\end{array}$ & $\begin{array}{l}\text { Uczniowie klas IV-VI } \\
\qquad \mathrm{N}=25\end{array}$ \\
\hline Owoc & - & $\begin{array}{l}\text { słodki owoc podobny do śliwki, eg- } \\
\text { zotyczny rodzaj pomarańczy, soczy- } \\
\text { sty, miessisty kolorowy owoc, bar- } \\
\text { dzo rzadki egzotyczny owoc, owoc } \\
\text { o smaku gorzko-słodkim z Afryki, } \\
\text { odmiana papai }\end{array}$ \\
\hline Warzywo & - & $\begin{array}{l}\text { podtużna dynia (po chińsku), za- } \\
\text { kręcony jak precelek bakłażan }\end{array}$ \\
\hline Potrawa & spaghetti jak sieci pajęcze & $\begin{array}{l}\text { chinska potrawa podawana } z \text { owo- } \\
\text { cami morza, odmiana sushi, nale- } \\
\text { śnik z dodatkiem bigosu, kromka } \\
\text { chleba ze smalcem, meksykański } \\
\text { hamburger, pajda chleba z nutella } \\
\text { i posypka }\end{array}$ \\
\hline Rzecz & $\begin{array}{l}\text { kolorowy okręt plywajacy, rodzaj } \\
\text { statku, ksiązka, w której sq baśnie } \\
\text { i legendy, trampolina, nowoczesny, } \\
\text { szybki samochód }\end{array}$ & $\begin{array}{l}\text { rysunek czarno-bialy, stary telewi- } \\
\text { zor, kapelusz z prostokatnym ron- } \\
\text { dem, wielka kolorowa chmura }\end{array}$ \\
\hline Osoba/postać z bajki & księżniczka & człowiek $z$ innej planety \\
\hline Stan emocjonalny & - & $\begin{array}{l}\text { wstręt przed noszeniem kanapek do } \\
\text { szkoty }\end{array}$ \\
\hline Zjawisko/sytuacja & pożegnanie & $\begin{array}{l}\text { sytuacja, kiedy kula rewolweru nie } \\
\text { leci do celu }\end{array}$ \\
\hline Rodzaj muzyki & - & $\begin{array}{l}\text { muzyka, w której wyrazy nie maja } \\
\text { znaczeń }\end{array}$ \\
\hline Miejsce & $\begin{array}{l}\text { przestrzeń między domami, świat } \\
\text { słodkości, kraina zbudowana z li- } \\
\text { zaków i waty cukrowej, kraina nad } \\
\text { morzem, kraina z górami, gdzie } \\
\text { chodza małe zwierzatka i świeci } \\
\text { słó́ce, to takie fajne miejsce, dżung- } \\
\text { la, miejsce z pałacem księżniczek, } \\
\text { bezludna wyspa, miejsce na szczycie } \\
\text { góry, dom, w którym można odpo- } \\
\text { czywać, kraina marzeń }\end{array}$ & $\begin{array}{l}\text { planeta, gdzie się podaje pajdy, pla- } \\
\text { neta z tęczowym wodospadem, pla- } \\
\text { neta, gdzie mieszka miś panda, } \\
\text { słodko-cukrowa planeta }\end{array}$ \\
\hline Zwierzę/zwierzęta & $\begin{array}{l}\text { rodzaj ptaka z irokezem, krokodyl } \\
z \text { duża paszcza, małe kotki, rodzaj } \\
\text { pieska (rasa) }\end{array}$ & - \\
\hline Pora roku & to wiosna & - \\
\hline
\end{tabular}

9 Zachowano oryginalną pisownię dzieci, poprawiono wyłącznie błędy ortograficzne. 
Paidia wyobrażana sobie przez dzieci jako owoc miała cechy wyjątkowości, egzotyczności i rzadkości. Często była kolorowa. Dzieci definiowały ją jak coś podobnego do znanego im obiektu (podobna do papai czy odmiany pomarańczy). Podczas opisu/definiowania dzieci prezentowały jej kształt, kolor i smak, rzadziej również zastosowanie, np.:

Paidia - jest to egzotyczny rodzaj pomarańczy. Posiada czarne plamy, a całość jest zielona. Jest do drugie podstawowe jedzenie dla pand, które maja dokładnie taka sama barwe jak paidia, czyli ten sam gatunek. Dla zwykłych pand jedzenie paidii jest szkodliwe. Może nawet zachorować na częstą chorobę „czasownik”, przez która panda doznaje dezorientacji w czasie.

Justyna, uczennica klasy VI

Opisy warzyw były bardziej lapidarne, ograniczały się do zasygnalizowania kształtu i/lub koloru (bez zastosowania/przeznaczenia warzywa), np. paidia to po chińsku podłużna dynia (Ewa, klasa VI) czy to zakręcony jak precelek bakłazan (Roman, klasa V).

Opisy potraw były zróżnicowane, od bardzo krótkich, np. odmiana sushi (Natalia, klasa VI), wyrażających brzmieniowe podobieństwo (paidia - pajda): pół dużej kromki chleba, zazwyczaj podawana ze smalcem (Mateusz, klasa V); po opisy bardziej szczegółowe: to taki naleśnik z dodatkiem bigosu, jabłek, pyz poznańskich $i$ wielu innych polskich potraw, które się w tym znajduje. I każdy robi tak, jak chce. Na dole jest naleśnik, a na samej górze znajduja się inne składniki (Marek, klasa VI).

Paidia jako rzecz miała cechy bajkowości (to książka, w której znajdują się baśnie i legendy), wyjątkowości, wiązała się z zabawą bezpośrednio (to trampolina, na której można skakać) lub pośrednio (jeden z uczniów narysował kapelusz przypominający ten z Małego Księcia) ${ }^{10}$. Nie wszystkie rzeczy były jednak kolorowe i wyjątkowe, zdarzały się i ponure, np.:

Paidia to stary telewizor. Ma dwie anteny, które przetwarzaja sygnał radiowy. Obraz paidii jest najczęściej czarno-biały i o niskiej rozdzielczości. Paidia dawniej oznaczała również „pudełko”. Dzisiaj paidię można znaleźć na strychu u babci lub w starym magazynie.

Mariusz, VI klasa

Paidia z tej definicji jest czymś niepożądanym, zapomnianym, prawie zapomnianym, o niskiej jakości.

Niezwykłością cechowała się paidia jako miejsce, najczęściej było w niej dużo kolorów, słodyczy, przyjemności (w kilku krainach — paidiach mieszkały misie pandy; kolejny raz dzieci podejmują zabawę słowem). Przykładowo:

${ }^{10}$ Kapelusz, pod którym coś innego jest ukryte. 
Paidia to słodka cukrowa planeta $w$ innym wymiarze. Nie jest ona zamieszkała przez żadne istoty ludzkopodobne, ale znajdziemy tutaj zwierzęta, takie jak te ziemskie, tyle że słodsze i zrobione $w 100 \%$ z cukru. Na przykład owce maja raciczki z lasek cukrowych, a odpowiednikiem naszej ziemskiej wetny jest wata cukrowa, z której da się zrobić identycznie to, co z naszej wetny. Wszystkie rzeczy na tej planecie maja witaminy i minerały, a w smaku nie sa tak słodkie, tylko niektóre odmiany takie są. Na Paidi wszystko jest jadalne oraz przepetnione kolorem i smakiem.

Aleksandra, klasa VI

Paidia $\mathrm{w}$ dziecięcych wyobrażeniach przybrała również postać księżniczki oraz nierzeczywistej postaci:

[...] jest to płeć damsko-męska. Jest to stworzenie z innej planety odnalezione $w$ dwudziestym pierwszym wieku. Nie jest ona podobna do mężczyzny ani do kobiety. Ma jednak te same kości, serce, krew, wszystko takie samo od środka.

Dawid, klasa V

Tabela 4

Przykłady rysunków dziecięcych uczniów z klas I-III

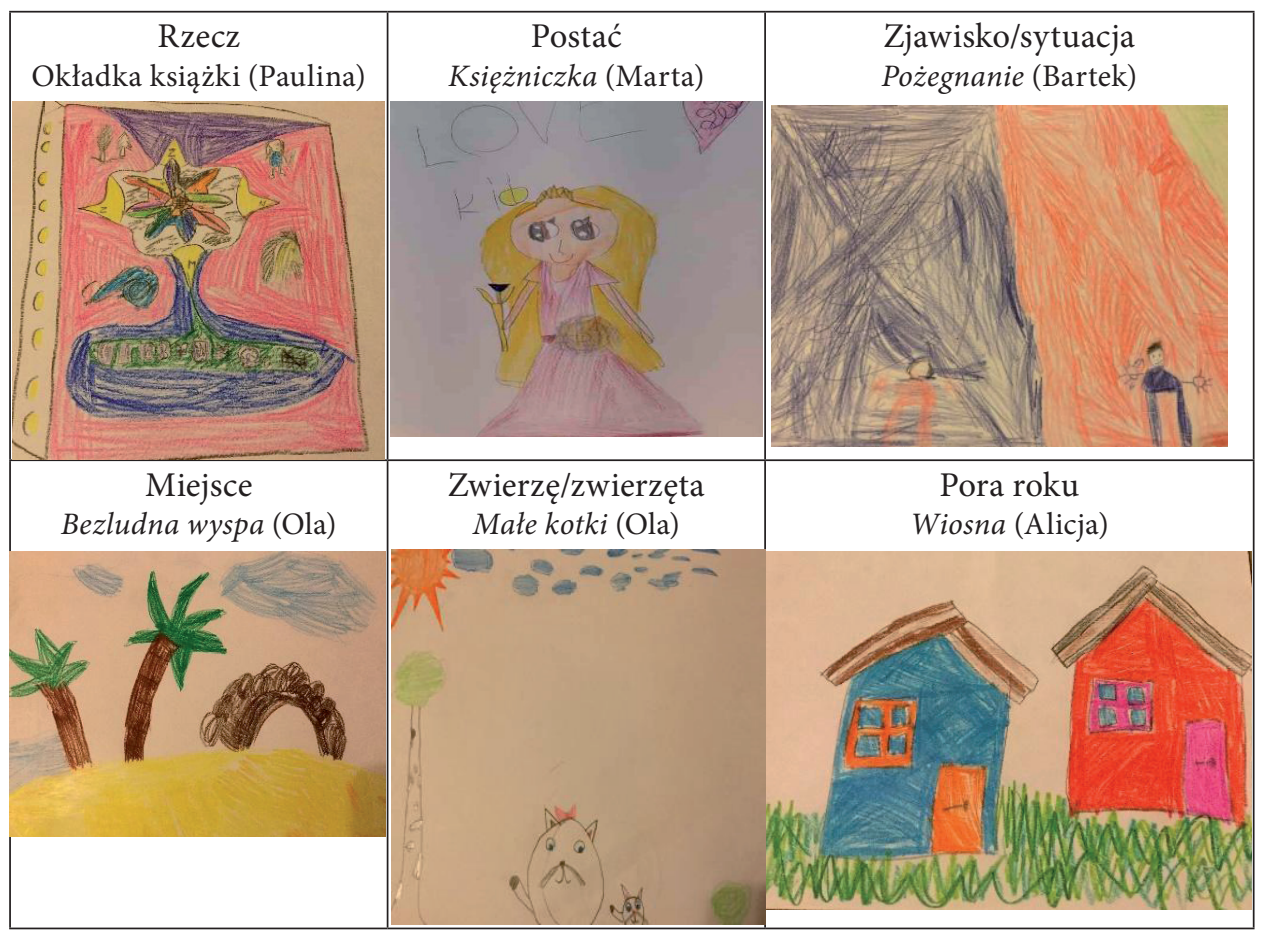


Przykłady rysunków dziecięcych uczniów z klas IV—VI

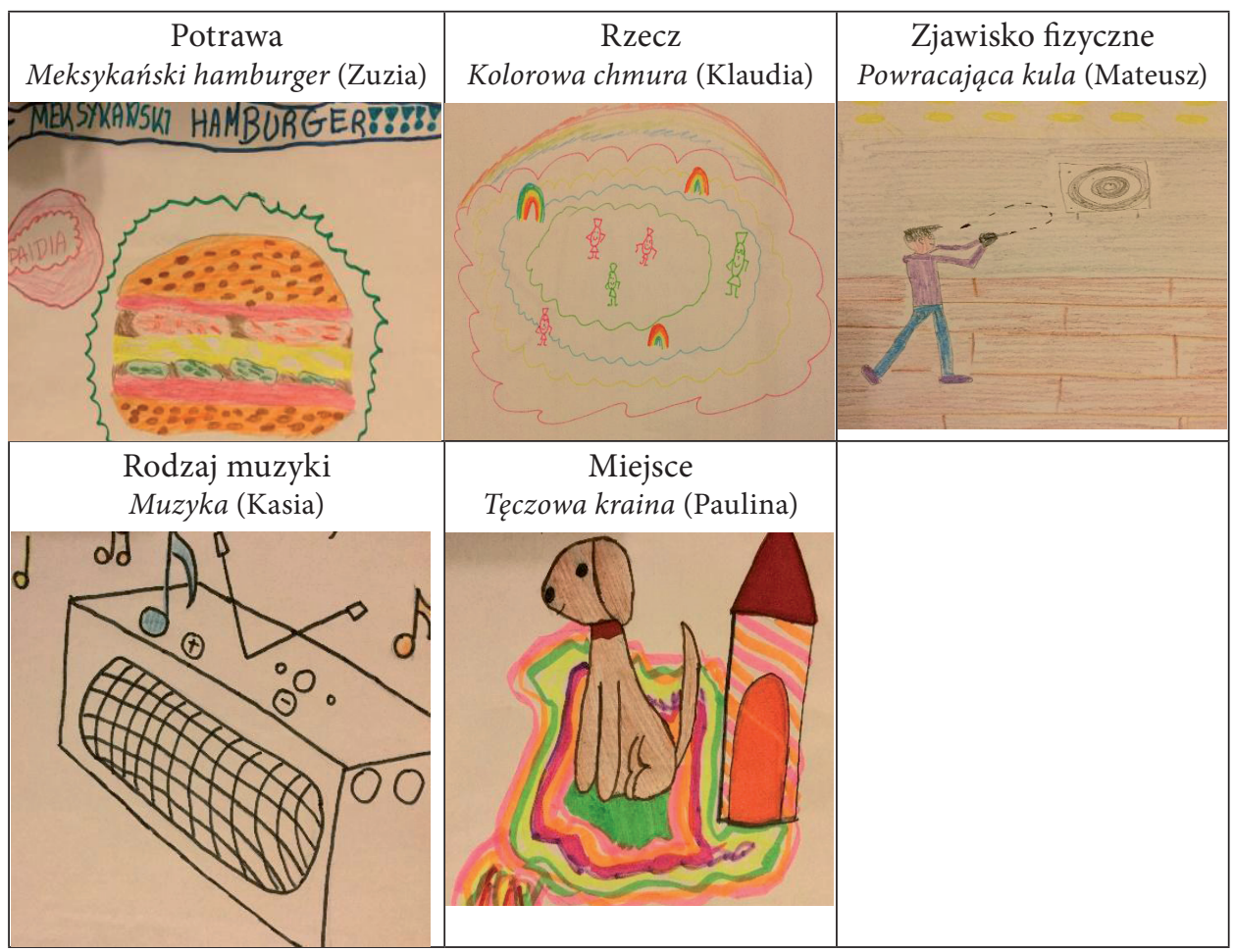

Paidię dzieci wyobrażały sobie również jako zwierzę (tylko uczniowie z klas I-III). Wskazywały podobieństwo wyobrażenia do realnego obiektu (krokodyla, psa, kota): stworzone (narysowane) przez nich zwierzęta były bardziej „podobne do" niż cechujące się dużą dawką niezwykłości. Dzieci dodawały im wymyślone komponenty, np. irokez (ptak z irokezem), lub określały tą nazwą znane im z rzeczywistości zwierzęta (paidia - krokodyl z duża paszcza).

Dzieci najczęściej wyobrażały sobie paidię jako rzecz (przedmiot, potrawę, warzywo, owoc), miejsce czy osobę/zwierzę. Zdecydowanie rzadziej paidią określały zjawisko, sytuację czy stan emocjonalny. Warto zauważyć, że właśnie w przypadku tych wyobrażeń przeważają takie, które niosą informacje czy emocje negatywne: wstręt (jest to wstręt przed kanapkami do szkoly. Objawia się odruchami wymiotnymi przy wyjmowaniu śniadania ze śniadaniówki, Dominik, klasa VI), rozstanie (kojarzy mi się z pożegnaniem) czy nawet możliwość zrobienia sobie krzywdy za pomocą kuli zbliżającej się w naszym kierunku (to bardzo rzadka sytuacja, kiedy kula $z$ rewolweru nie leci do celu, tylko robi zwrot i trafia do ciebie, Mateusz, klasa V).

Przyjrzyjmy się - poza definicjami/opisami - rysunkom dzieci. W tabelach 4.-5. zostały zebrane przykłady konkretyzacji plastycznych uczniów. 
Zdecydowana większość prac uczniów przedstawiała elementy pozytywne: rysunki były kolorowe i pełne życia, paidia kojarzyła się z czymś miłym, kolorowym i przyjemnym. Elementy negatywne, szare, ponure, związane z pejoratywnie ocenianą emocjonalnością, prezentowane były stosunkowo rzadko (jak już wcześniej wspomniałam, dotyczyły głównie sensu paidii jako cechy/stanu/sytuacji oraz rzeczy). W badanej grupie wszystkie definicje i rysunki, które można zaklasyfikować jako kojarzące się negatywnie, podali lub wykonali chłopcy. Szczegółowa analiza tej zależności została zilustrowana w tabeli 6 .

Tabela 6

Elementy pozytywne i negatywne na rysunkach dzieci oraz w tworzonych opisach/definicjach

\begin{tabular}{|l|c|c|}
\hline & $\begin{array}{c}\text { Uczniowie klas I-III } \\
\mathrm{N}=26\end{array}$ & $\begin{array}{c}\text { Uczniowie klas IV-VI } \\
\mathrm{N}=25\end{array}$ \\
\hline $\begin{array}{l}\text { Elementy negatywne, wyrażające negatywne } \\
\text { emocje, sytuacje, negatywne postaci, elemen- } \\
\text { ty ponure, czarno-białe, niedziałające lub sła- } \\
\text { bej jakości }\end{array}$ & 1 & 4 \\
\hline Elementy pozytywne, kolorowe & 25 & 21 \\
\hline Razem & 26 & 25 \\
\hline
\end{tabular}

\section{Podsumowanie i wnioski}

Badani uczniowie wyobrażali sobie paidię jako rzecz (jadalną: owoc, warzywo, potrawę), przedmiot (służący do zabawy, np. samochód czy trampolina, lub inny użytkowy przedmiot) albo miejsce (egzotyczne, wesołe, zawierające przyjemne elementy, np. postaci znajdujących się tam zwierząt czy pysznych słodyczy). Zdecydowanej większości dzieci paidia kojarzyła się z czymś pozytywnym. Negatywne odnosiły się do opisu paidii zjawiska, paidii stanu emocjonalnego oraz paidii rzeczy. Sporadycznie uczniowie w swoich wyobrażeniach i opisach wykorzystywali grę słów, np. podobieństwo brzmieniowe paidii i pandy czy pajdy. Warto byłoby powtórzyć te badania wśród dzieci młodszych, od trzy- do sześcioletnich, których wyobraźnia jest u szczytu możliwości. Po rozpoczęciu edukacji w szkole spontaniczność i kreatywność dzieci są ograniczane. Nierzadko niczym nieskrępowana twórczość przekształca się w odtwórczośćc ${ }^{11}$. Wyobraźnia twórcza jest „procesem przynoszącym nowe wyobrażenia, opierające się wprawdzie na materiale dawnych spostrzeżeń, lecz odbiegające od nich

11 Więcej na temat ograniczeń stawianych przez szkołę oraz ich skutków piszą Dorota Klus-Stańska oraz Marzenna Nowicka w książce: Sensy i bezsensy edukacji wczesnoszkolnej. Por. Klus-Stańska, Nowicka, 2005. 
w sposób przekraczający jałowe, zwykłe modyfikacje, właściwe wyobraźni odtwórczej" (Pietrasiński, 1969, s. 26) Niech zilustrowaniem twórczych możliwości i nieskrępowanej wyobraźni będzie rysunek czteroletniej Poli, która wyobraża sobie paidię jako coś takiego, co ma dużo kolorów, i takie kropeczki i jest zabawne. Jakże doskonale ta praca koresponduje z zabawą, kolorem, żywiołowością, stanowi dowód na niczym nieskrępowane możliwości twórczej wyobraźni najmłodszych.

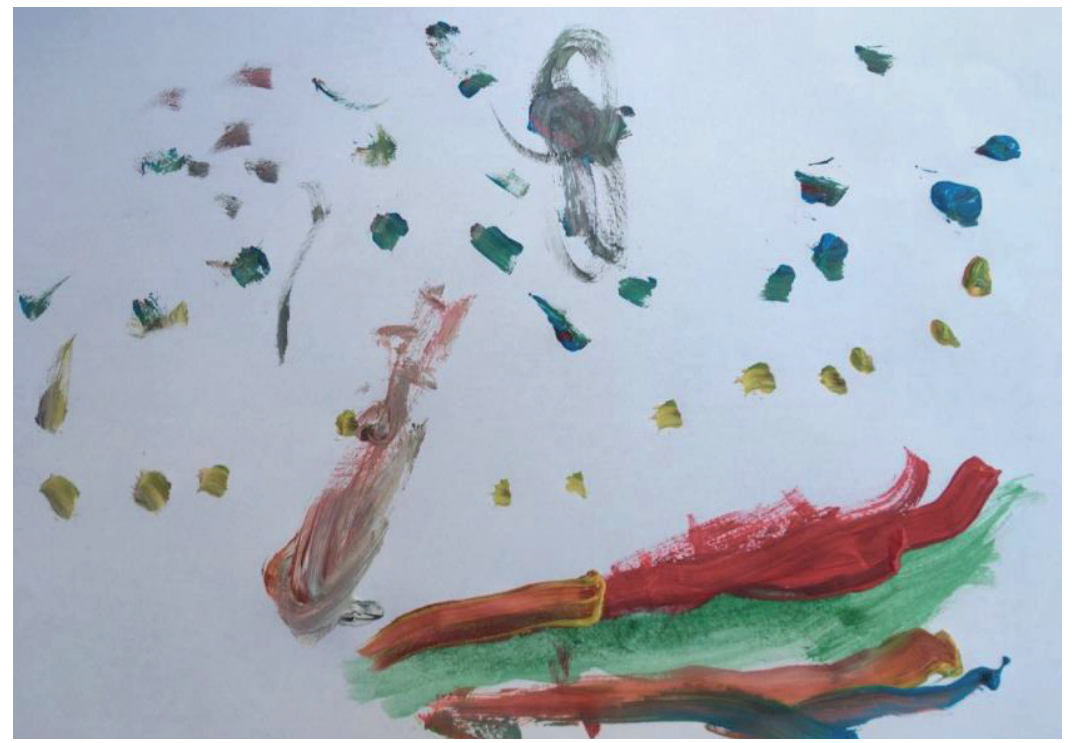

\section{Literatura}

Bańko M., red., 2000, Inny słownik języka polskiego PWN, Warszawa.

Bańko M., red., 2003, Wielki słownik wyrazów obcych PWN, Warszawa.

Caillois R., 1973, Żywioł $i$ ład, Tatarkiewicz A., przeł., Warszawa.

Czyż A., Podrez E., 2002, Wyobraźnia jako jaźń twórcza. Studia z etyki, literatury i sztu$k i$, Warszawa.

Dobrołowicz W., 1991, Wybrane problemy psychologii wyobraźni, „Kieleckie Studia Pedagogiczne i Psychologiczne", t. 5.

Dubisz S., red., 2003, Uniwersalny słownik języka polskiego PWN, Warszawa.

Falkowski A., Maruszewski T., Nęcka E., 2011, Procesy poznawcze, w: Strelau J., Doliński D., red., Psychologia akademicka. Podręcznik, t. 2, Gdańsk.

Francuz P., 2007, Teoria wyobraźni Stephena Kosslyna. Próba reinterpretacji, w: Francuz P., red., Obrazy w umyśle. Studia nad percepcja i wyobraźnią, Warszawa.

Górniewicz J., 1992, Rozwój i kształtowanie wyobraźni dziecka, Toruń-Warszawa. http://www.ling.pl/index.jsp [data dostępu: 15.06.2018]. 
https://repozytorium.ukw.edu.pl/bitstream/handle/item/3051/Dorota\%20Maria\%20Jankowska\%20Profilowa\%20diagnoza\%20wyobraZni\%20tworczej\%20prezentacja\%20 nowej\%20koncepcji\%20teoretycznej\%20i\%20narzedzia.pdf?sequence=1 [data dostępu: 12.10.2018].

Jaeger W., 1962, Paideia, Plezia M., przeł., Warszawa.

Jankowska D.M., 2015, Profilowa diagnoza wyobraźni twórczej - prezentacja nowej koncepcji teoretycznej i narzędzia, „Przegląd Pedagogiczny”, nr 1.

Klus-Stańska D., Nowicka M., 2005, Sensy i bezsensy w edukacji wczesnoszkolnej, Warszawa.

Limont W., 1996, Analiza wybranych mechanizmów wyobraźni twórczej. Badania eksperymentalne, Toruń.

Ostasz M., 2011, Paidia Konopnickiej, Tuwima i Sztaudyngera, „Kwartalnik Opolski”, nr $2 / 3$.

Pietrasiński Z., 1969, Myślenie twórcze, Warszawa.

Rozet I., 1982, Psychologia fantazji. Badanie twórczej aktywności umysłowej, Nowińska A., przeł., Warszawa.

Sartre J.P., 1940, Wyobrażenie. Fenomenologiczna psychologia wyobraźni, Beylin P., przeł., Warszawa.

Selye H., 1967, Od marzenia do odkrycia naukowego, Zembrzuski L., Serzysko W., przeł., Warszawa.

Tokarski J., red., 1980, Słownik wyrazów obcych, Warszawa.

Vygotsky L.S., 2004, Imagination and Creativity in Childhood, "Journal of Russian and East European Psychology", no. 42/1.

Ward T.B., 1994, Structured Imagination: The Role of Category Structure in Exemplar Generation, "Cognitive Psychology”, no. 27.

Winczer P., 1976, Element zabawowy w poezji awangardowej (na przykładzie czeskiego poetyzmu), „Teksty. Teoria Literatury, Krytyka, Interpretacja”, nr 25/1.

Zdankiewicz-Ścigała E., Maruszewski T., 2008, Wyobrażenia jako pierwsza forma doświadczenia generowanego przez jednostkę, w: Strelau J., red., Psychologia. Podręcznik akademicki, t. 2, Gdańsk.

Anna Guzy - doktor nauk humanistycznych, językoznawca, psycholog, trener emisji głosu, psychoterapeuta (w trakcie szkolenia), adiunkt w Katedrze Dydaktyki Języka i Literatury Polskiej Uniwersytetu Śląskiego. Autorka publikacji z zakresu dydaktyki języka polskiego, emisji głosu oraz języka dziecka. Współautorka książki Czas na... Język i dydaktyka w badaniach młodych naukowców (Katowice 2015); współredaktorka trzech tomów z zakresu pracy z uczniem o specjalnych potrzebach edukacyjnych, autorka i współautorka blisko 60 publikacji.

e-mail: anna.guzy@us.edu.pl 
